\title{
Going gently
}

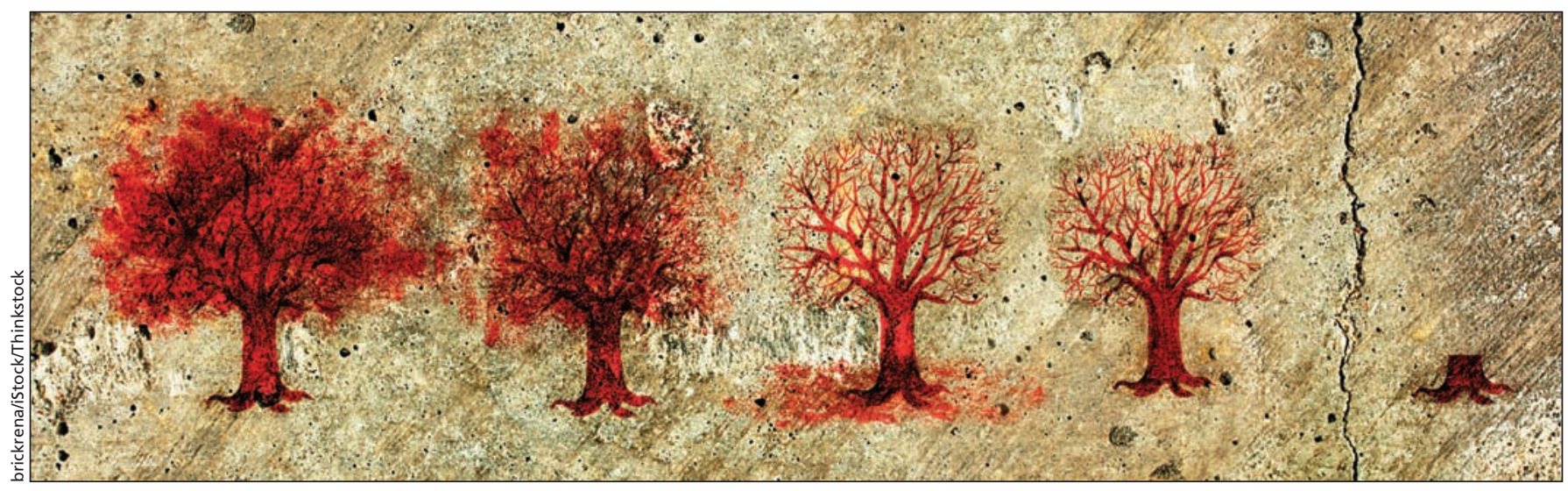

Perhaps, if placed in that same situation, we might not go gently into that good night either. - Robert Macauley ${ }^{1}$

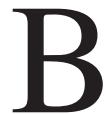
etty was fighting for her life. At age 58, end-stage ovarian cancer was taking a toll. Her body was worn out, and her abdomen was tattooed with scars. Two bags dangled from her sides, one a colostomy, the other a collection of milky debris from an internal abscess. Still, Betty wanted further treatment. Her physicians believed the burden of treatment outweighed any benefits and were reluctant to offer conciliatory chemotherapy. They lamented that Betty was clouded to the reality of her illness, and they asked that I talk with her to help define realistic goals of care.

I knocked on her door, entered and introduced myself. The sweaty smell of sickness saturated the room. She told me to have a seat, and before I could speak, she began.

"My mother died of this same disease at 78 . So I know what I'm up against, I know exactly."

I pulled my chair close to her bed and let her talk.

"Bags hang from my body, one gathering a constant trickle of liquid sewage, the other a disgusting pool of sludge from an abscess. I have been hollowed out. Everything inside of me has been removed - everything. I'm empty, both my body and my heart."

She wiped a tear and leaned on her elbow, her belly bulged with metastases. "Many days I feel there are things worse than death, but then, I don't want to die. I really don't want to die. Does that make sense?"

I leaned forward, held her hand and told her that many people with cancer have similar feelings, and truth be told, no one really wants to die.

"There are days when the only part of me that feels alive is the suffering. When do I let go? When is the time?"

"You will know when it's time to let go," I told her. "Your heart will tell you."

Then she stared at me intently, without blinking.

"How long do you think I have?"

"I think a few weeks," I said. The words passed over my lips so easily, I felt ashamed. What must it feel like to know you have only weeks to live?

Her head hung as she spoke, more to herself than to me. "I did all of this, the surgery, the chemotherapy, and for what?"

I told her we're only human, we do what we think is right at the time, and her decision was the right decision for that moment.

"What about hospice?" I asked.

She paused, looked out the window, fidgeted with her cell phone and took a deep breath.

"No, I think it's too early for hospice."

She was clearly torn between living and dying, a kind of pulling back and forth, ${ }^{2}$ wanting to live, while at times, wanting to die. It's a contradiction common among the dying. But, "I am going to die" is distinct from "I am dying," ${ }^{3}$ and Betty was clearly rooted in the former - at least for now. She was reconciled to death, just not at this time.

"I think it's too early," she said again. "I want more treatment."

I told her no one really knows whether continued treatment is the right or wrong choice. Many who choose treatment do suffer horribly, while others gain months to a year or more of time, time that can be the most treasured days of a person's life.

I leaned over and gave Betty a hug.

"It's your choice," I told her, "and your choice is the right choice."

As I left Betty's room, I thought back to seven years past, when I let my wife go - turned off her pacemaker and defibrillator and watched her die as her heart beat erratically until the undulating choreography of the EKG collapsed into a flat line. It was the most difficult thing I ever had to do, and I wavered in my decision many times — just like Betty.

\section{Paul Rousseau MD}

Medical Director, Palliative and Supportive Care, Medical University of South Carolina, Charleston, SC

\section{References}

1. Macauley R. Patients who make "wrong" choices. J Palliat Med 2011;14:13-6.

2. Schwartz M. Morrie: in his own words. New York: Delta Trade Paperbacks; 1996.

3. Gubar S. Enduring ovarian cancer: memoir of a debulked woman. New York: W.W. Norton; 2012.

All characters in this work are fictitious. Any resemblance to real persons, living or dead, is purely coincidental.

CMAJ 2015. DOI:10.1503/cmaj.140614 